\title{
Mesquite and grass interference with establishing redberry juniper seedlings
}

\author{
W.R. TEAGUE, S.L. DOWHOWER, S.G. WHISENANT AND E. FLORES-ANCIRA
}

Authors are associate professor and research associate, Texas Agricultural Experiment Station, Vernon, Texas 76385, professor and graduate student, Department of Rangeland Ecology and Management, College Station, Texas 77843.

\begin{abstract}
Excessive cover of juniper (Juniperus pinchotii Sudw.) reduces forage production, interferes with livestock management, and diminishes the watershed and wildlife habitat values of rangelands. We studied whether juniper seedlings were differentially suppressed in the presence of different grass species, and to what extent established mesquite (Prosopis glandulosa Torr.) trees facilitated or competed with establishing juniper seedlings. Seedlings growing with any of the grasses (RGR $=0.23$ to 0.43 $\mathrm{cm} \mathrm{cm} \mathrm{cm}^{-1}$ ) grew significantly less than those with no grass competition $\left(R G R=0.72 \mathrm{~cm} \mathrm{~cm}^{-1}\right)(P<0.01)$. Juniper seedlings grew significantly less in the presence of buffalograss (Buchloe dactyloides (Nutt.) Engelm.) $\left(\right.$ RGR $=0.23 \mathrm{~cm} \mathrm{~cm}^{-1}$ than with either sideoats grama (Bouteloua curtipendula (Michx.) Torr.) $($ RGR $=0.43 \mathbf{c m}$ $\left.\mathrm{cm}^{-1}\right)$ or tobosagrass (Hilaria mutica $[$ Buckl.] Benth. $)($ RGR $=$ $\left.0.43 \mathrm{~cm} \mathrm{~cm}^{-1}\right)(P<0.01)$. In contrast, juniper seedlings grew larger under intact canopies of mesquite $\left(R G R=0.99 \mathrm{~cm} \mathrm{~cm}^{-1}\right)$ than in open grassland $\left(R G R=0.65 \mathrm{~cm} \mathrm{~cm}^{-1}\right)(P<0.05)$ due in part to the greater nutrient availability $(P<0.05)$ under mesquite canopies. Juniper growing in sub-canopy positions with mesquite trees removed grew less $\left(R G R=0.84 \mathrm{~cm} \mathrm{~cm}^{-1}\right)$ than those growing under mesquite canopies with root competition $\left(\right.$ RGR $\left.=0.99 \mathrm{~cm} \mathrm{~cm}^{-1}\right)(\mathrm{P}<0.05)$. Juniper growing under intact mesquite canopies but without mesquite root competition, grew no better or worse $\left(\operatorname{RGR}=0.93 \mathrm{~cm} \mathrm{~cm}^{-1}\right)$ than those with mesquite root competition $\left(R G R=0.99 \mathrm{~cm} \mathrm{~cm}^{-1}\right)(P>0.05)$, indicating that mesquite root competition with juniper is probably inconsequential. Since junipers grow mainly in fall, winter and spring when mesquite trees are dormant and leafless, the lack of competition may largely be due to these 2 species using resources at different times of the year. Greater nutrient availability beneath mesquite canopies, reduction of summer temperatures, and temporal separation of resource use clearly benefit juniper seedlings growing in the presence of mesquite. Managing for a vigorous grass component with low densities and cover of mesquite is the best way to limit the rate of invasion by juniper.
\end{abstract}

Key Words: Competition, facilitation, mesquite rangeland, seedling establishment

Funding from the E. Paul and Helen Buck Waggoner Foundation Inc. and the Texas Agricultural Experiment Station is gratefully acknowledged. We thank Keith Owens and Don Robinson for reviewing the manuscript.

Manuscript accepted 29 Dec. 00.

\section{Resumen}

La cubierta excesiva de "Juniper" (Juniperus pinchotii Sudw.) reduce la producción de forraje, interfiere con el manejo del ganado y disminuye el valor del pastizal como cuenca hidrológica y hábitat de fauna silvestre. Estudiamos si las plántulas de “" Juniper" fueron diferencialmente suprimidas en presencia de diferentes especies de zacates y en que magnitud los árboles establecidos de "Mesquite" (Prosopis glandulosa Torr.) facilitaron o compitieron con el establecimiento de plántulas de " Juniper . Las plántulas creciendo con cualquiera de los zacates. Las plántulas creciendo con cualquier zacate $(\mathrm{RGR}=\mathbf{0 . 2 3}$ a 0.43 $\mathrm{cm} \mathrm{cm} \mathrm{cm}^{-1}$ ) crecieron significativamente menos que aquellas sin competencia de zacates $\left(\right.$ RGR $\left.=0.72 \mathrm{~cm} \mathrm{~cm}^{-1}\right)(P<0.01)$. Las plántulas de "Juniper" crecieron significativamente menos en presencia de "Buffalograss" (Buchloe dactyloides (Nutt.) Engelm.) $\left(\right.$ RGR $\left.=0.23 \mathrm{~cm} \mathrm{~cm}^{-1}\right)$ que en presencia de "Sideoats grama" (Bouteloua curtipendula (Michx.) Torr.) $(\mathrm{RGR}=0.43 \mathrm{~cm}$ $\left.\mathrm{cm}^{-1}\right)$ "Tobosagrass" (Hilaria mutica [Buckl.] Benth.) $($ RGR = $\left.0.43 \mathrm{~cm} \mathrm{~cm}^{-1}\right)(\mathrm{P}<0.01)$. En contraste, las plántulas de "Juniper" crecieron más grandes bajo las copas intactas de "Mesquite" $\left(\right.$ RGR $\left.=0.99 \mathrm{~cm} \mathrm{~cm}^{-1}\right)$ que en el pastizal abierto $($ RGR $=0.65 \mathrm{~cm}$ $\left.\mathrm{cm}^{-1}\right)(\mathrm{P}<0.05)$ debido en parte a la mayor disponibilidad de nutrientes $(P<0.05)$ bajo las copas de los “ Mesquite”. Las plántulas de "Juniper" creciendo en posiciones de sub-copa con árboles de "Mesquite" removidos crecieron menos $(\mathrm{RGR}=\mathbf{0 . 8 4}$ $\mathrm{cm} \mathrm{cm} \mathrm{cm}^{-1}$ ) que aquellas creciendo bajo las copas de "Mesquite" con competencia de raíz. $\left(\right.$ RGR $\left.=0.99 \mathrm{~cm} \mathrm{~cm}^{-1}\right)(P<0.05)$. Las plántulas de "Juniper" creciendo bajo copas intactas de "Mesquite" pero sin competencia de raíz ni creció mejor ni peor $\left(\right.$ RGR $\left.=0.93 \mathrm{~cm} \mathrm{~cm}^{-1}\right)$ que aquellas con competencia de raíz del “ Mesquite" ( $R$ GR=0.99 $\left.\mathrm{cm} \mathrm{cm}^{-1}\right)(P>0.05)$, indicando que la competencia de raíz de "Mesquite" con el "Juniper" es probablemente insignificante. Dado que el “Juniper" crece principalmente en otoño, invierno y primavera cuando los árboles de "Mesquite" están dormantes y defoliados, la falta de competencia puede deberse en gran parte a que estas 2 especies utilizan los recursos en diferentes tiempos del año. La mayor disponibilidad de nutrientes bajo las copas de "Mesquite", la reducción de las temperaturas de verano y la separación temporal del uso de recursos beneficia claramente a las plántulas de Juniper" creciendo en presencia de "Mesquite". El manejar para mantener un componente vigoroso de zacate con bajas densidades y cobertura de "Mesquite" es la mejor manera de limitar la tasa de invasión del "Juniper. 
Juniper (Juniperus pinchotii Sudw.) reduces grass productivity, especially on shallow soils by altering the light environment, soil water content, soil nutrient availability, and soil thermal regime (Scifres 1980). In addition, excessive cover of these woody plants interferes with movement and handling of livestock and diminishes watershed and wildlife habitat values of rangelands (Scifres 1980, Dye et al. 1995, Fuhlendorf et al. 1996, Johnson et al. 1999). Competition from neighboring plants does not strongly influence the growth rate of young, established juniper but delays reproductive maturity (McPherson and Wright 1987). However, neighboring plants reduce the growth of juniper seedlings in the establishment phase (Van Auken 1993). For example, Smith et al. (1975) report the suppression of juniper seedlings by blue grama (Bouteloua gracilis (H.B.K) Lag. ex Steud), and Jackson and Van Auken (1997) report that establishing juniper plants survived and grew better at the edge of established woodlands than in adjacent grassland.

Knowledge of the relationship between establishing juniper seedlings and associated species may provide insights to developing management strategies for the control of juniper invasion. This study examines 1) whether juniper seedlings are differentially suppressed by major associated grasses, and 2) to what extent established mesquite (Prosopis glandulosa Torr.) trees facilitate or compete with establishing juniper seedlings.

\section{Methods}

This study was conducted on the Y Experimental Ranch (YER), located $25 \mathrm{~km}$ southwest of Crowell $\left(33^{\circ} 52^{\prime} \mathrm{N}, 100^{\circ} 00^{\prime}\right.$ $\mathrm{W})$ in north central Texas. The climate is continental with an average of 220 frostfree growing days. Mean annual precipitation at Crowell is $617 \mathrm{~mm}$, varying from 260 to $990 \mathrm{~mm}$, with peaks in May and September. Annual mean monthly temperature is $17.4^{\circ} \mathrm{C}$, ranging from $36.4^{\circ} \mathrm{C}$ in July to $-2.3^{\circ} \mathrm{C}$ in January. Elevation is 500 $\mathrm{m}$ at the research site and slope is 1 to $3 \%$.

Mesquite trees dominate the vegetation, providing approximately $50 \%$ cover over the experimental area. Junipers have been invading this site, with plants being up to 2$\mathrm{m}$ tall and providing up to $5 \%$ cover. Dominant herbaceous species include tobosagrass (Hilaria mutica [Buckl.] Benth.), sideoats grama (Bouteloua curtipendula (Michx.) Torr.), Texas wintergrass (Nassella leucotricha (Trin. \& Rupr.) Pohl), buffalograss (Buchloe dactyloides
(Nutt.) Engelm.), annual broomweed (Gutierrezia texanum ((DC.) Torr. \& A. Gray), and western ragweed (Ambrosia psilostachya DC.). Soil is a Tilman clay loam (fine, mixed, thermic Typic Paleustoll).

\section{Grass competition study}

In June 1994, 60 juniper seedlings 15 to $18 \mathrm{~cm}$ tall were located in open grassland of approximately 5 ha where woody plant cover was less than $10 \%$. Twenty seedlings per grass species were located growing in patches of grass dominated by sideoats grama, tobosagrass, or buffalograss. These selected patches were at least $1.5 \mathrm{~m}$ in diameter.

Ten of these juniper seedlings were selected as controls around which all herbaceous vegetation for a radius of 0.75 $\mathrm{m}$ at ground level was cleared with a hoe whilst leaving existing litter in place and minimizing disturbance of the soil surface. These areas were kept free of all plants except the juniper seedlings at the centers by hand removal at least monthly. All seedlings were caged to avoid damage by large mammals. Cages were $0.5-\mathrm{m}$ in diameter and constructed out of wire with mesh-size of $15-\mathrm{cm}$. Basal diameter and plant height were measured initially in June 1994 and final measures were taken in November 1996. Basal diameter (mm) was measured with calipers at ground level, avoiding irregular stem thickening. Height was measured from ground level with a ruler to the nearest $0.5 \mathrm{~cm}$.

Herbaceous cover at the experimental site was estimated visually using $0.05-\mathrm{m}^{2}$ quadrats $(20 \times 25-\mathrm{cm})$ along 8 , thirty meter straight-line transects located at random. A total of 40 quadrats were used in each March, July and November of both 1994 and 1995. Cover of grass species, forbs, litter and bare ground were estimated visually in each quadrat.

\section{Mesquite competition study}

This study was conducted at the same time as, and adjacent, to the grass competition study above. Mesquite cover was approximately $50 \%$. Ten juniper seedlings $15-18 \mathrm{~cm}$ tall with intact soil root cores 8 $\mathrm{cm}$ in diameter and $15 \mathrm{~cm}$ deep were selected and transplanted into each of the following situations:

1. Under mesquite canopies,

2. Under mesquite canopies where the tree had been removed at ground level,

3 . Under mesquite canopies where a 1.0$\mathrm{m}^{2}$ area $50 \mathrm{~cm}$ deep was isolated from root competition, and

4. In open grassland.

Even though juniper seedlings occur naturally under established mesquite trees, it was impossible to find sufficient replications for this study under natural conditions. Transplanting ensured that juniper seedling size, mesquite tree size, and the location of juniper seedlings under the tree canopy were relatively uniform. All transplants were located midway between the tree stem and canopy edge to the north of mature mesquite trees 2.5 to $3 \mathrm{~m}$ tall. All other woody plants under the canopies of these trees were removed at ground level with secateurs immediately before transplanting in June 1994. Seedlings were given 4 liters of water every 2 weeks from June through August 1994 to ensure establishment. Mesquite trees were removed in January 1995 using a chainsaw and the exposed, ground level stumps were painted with diesel oil to prevent regrowth. Root isolation was accomplished by digging an $8 \mathrm{~cm}$ wide trench, $50 \mathrm{~cm}$ deep in a circle with a radius of $564 \mathrm{~mm}\left(=1.0 \mathrm{~m}^{2}\right)$ with a juniper seedling planted in the center. The trench walls were lined with heavy-duty plastic to maintain horizontal isolation. The 7 most vigorous plants in each treatment were measured as replicates. All seedlings were caged to avoid damage as in study 1 . Basal diameter and plant height were measured initially in June 1994 and final measures were taken in November 1996 as per the above study.

Soil temperature was measured on 6 days in June 1996 at 1- and 2.5-cm soil depths in open grassland and under mesquite canopies. In the open grassland measurements were made in the following situations; bare ground, shortgrass (buffalograss), tallgrass (sideoats grama or tobosagrass). Measurements $(n=6)$ were made at 0800, 1000, 1200 and 1500 hours on each day at each of these positions. Soil water was measured monthly with a neutron probe at an adjacent site under mesquite canopies ( 9 access tubes) and in open grassland ( 5 access tubes) at the following depths: 0 to 150,150 to 300,300 to 600,600 to 900 and 900 to $1200 \mathrm{~mm}$.

Soil samples were taken in June 1996 to determine soil fertility differences between the open grassland and under the mesquite canopy positions listed above. In each, 2 random samples were taken at each of the following 4-soil depths: 0 to 150,150 to 300,300 to 600 and 600 to $900 \mathrm{~mm}$. The samples were calcareous and analyses to correct for $\mathrm{CaCO}_{3}$ were performed using the equation:

Organic $\mathrm{C}=$ Total $\mathrm{C}-\mathrm{C}$

from calcite/dolomite

Total carbon was obtained by heating a 
Table 1. Cover (\%) composition of patches dominated by different grasses.

\begin{tabular}{lccccc}
\hline \hline Patch dominant & $\begin{array}{c}\text { Dominant } \\
\text { grass }\end{array}$ & $\begin{array}{c}\text { Other } \\
\text { grasses }\end{array}$ & Forb & Litter & $\begin{array}{c}\text { Bare } \\
\text { ground }\end{array}$ \\
\hline Sideoats grama & $51 \mathrm{a}^{1}$ & $4 \mathrm{~b}$ & $5 \mathrm{a}$ & $26 \mathrm{ab}$ & $13 \mathrm{ab}$ \\
Buffalograss & $48 \mathrm{a}$ & $8 \mathrm{a}$ & $8 \mathrm{ab}$ & $22 \mathrm{~b}$ & $14 \mathrm{a}$ \\
Tobosagrass & $43 \mathrm{~b}$ & $9 \mathrm{a}$ & $9 \mathrm{~b}$ & $29 \mathrm{a}$ & $10 \mathrm{~b}$ \\
\hline
\end{tabular}

${ }^{1}$ Means in the same column with the same letter are not significantly different $(\mathrm{P}>0.05)$.

2-g sample to $950^{\circ} \mathrm{C}$, passing oxygen over the sample and collecting the $\mathrm{CO}_{2}$ in ascarite (Nelson and Sommers 1982). The content of calcite and dolomite was determined by a gasometric procedure after Dreimanis (1962). The P, K, Ca, Mg, Na and $\mathrm{S}$ contents were determined using the method of Hons et al. (1990) and pH was determined using the method of Schofield and Taylor (1955). The $\mathrm{N}$ content is expressed on a mg $\mathrm{NO}_{3}-\mathrm{N} \mathrm{kg}^{-1}$ basis and was determined using the method of Keeney and Nelson (1982).

\section{Statistical analyses}

To account for differences in initial plant size, relative growth rates for the 2year growth period are used in analyses (as per Evans 1972). Data were analyzed using analysis of variance and the Tukey means separation test (SAS Institute 1988) to test for differences in growth of juniper seedlings in the presence of different grasses in the grass competition study, soil temperature and soil nutrient status. The general linear model (SAS Institute 1988) was used to test for differences in herbaceous cover and treatment effects on juniper growth in the mesquite competition study.

\section{Results and Discussion}

\section{Environmental measurements}

Each patch containing juniper seedlings was comprised almost entirely of a single species. Cover of other grasses and forbs in each patch type was less than $10 \%$ (Table 1). Sideoats grama patches contained less other grasses and forbs $(\mathrm{P}<0.01)$ than buffalograss and tobosagrass patches. Litter cover and bare ground was similar in patches dominated by different grasses.

Soil temperature in each of the vegetation types differed $(\mathrm{P}<0.0001)$. Temperatures did not differ $(\mathrm{P}>0.05)$ between bare ground and beneath shortgrasses or between tallgrasses and mesquite canopies $(\mathrm{P}>0.05)$. However, soil temperature in the tallgrass and under mesquite canopies was cooler than in bare ground and shortgrass vegetation $(\mathrm{P}<$ $0.05)$. Time of day influenced soil temperature $(\mathrm{P}<0.0001)$. Soil temperature started the same at 0800 hours and then diverged between vegetation types $(\mathrm{P}<$ $0.0001)$ as the day temperature increased (Fig 1). In all vegetation types, soil temperature was significantly higher at 1200 than earlier in the day $(\mathrm{P}<0.05)$, but was not different at $1500(\mathrm{P}>0.05)$.

Soil water content in open grassland and under mesquite canopies was not different $(\mathrm{P}=0.59$ for brush * soil depth interaction). However, soil water content in open grassland at 600 to $900 \mathrm{~mm}$ and 900 to
$1,200 \mathrm{~mm}$ depths was lower $(\mathrm{P}<0.05)$ than in shallower soil layers of the grassland patches, and all soil layers under mesquite canopies. Soil nutrient analyses indicate greater $\mathrm{Mg}, \mathrm{S}$, and $\mathrm{Na}$ contents at $300 \mathrm{~mm}$ to $900 \mathrm{~mm}$ than at other depths (Table 2). Gypsum is associated with these depths and this layer is often impervious and can present a barrier to root penetration. The $\mathrm{C}$ and $\mathrm{N}$ contents were lower but $\mathrm{S}$ content was higher $(\mathrm{P}<0.05)$ in open grassland soils than in any of the mesquite canopy locations. Other nutrient contents were not different between vegetation types (Table 2). Soils beneath mesquite canopies have been found to have higher $\mathrm{C}$ and $\mathrm{N}$ contents than the surrounding grassland (Barth and Klemmedson 1978, 1982, Virginia et al. 1992).

\section{Grass competition study}

Juniper seedlings grew more in basal diameter and height $(\mathrm{P}<0.01)$ where all grass was removed than in the presence of any grasses (Table 3 ). Those growing with

Table 3. Relative growth rate (RGR) of juniper seedlings growing in the presence of different grass species.

\begin{tabular}{lcc}
\hline \hline Treatment & $\begin{array}{c}\text { RGR } \\
\text { Basal diameter }\end{array}$ & $\begin{array}{c}\text { RGR } \\
\text { Plant height }\end{array}$ \\
\hline Control & $\left(\mathrm{mm} \mathrm{mm}^{-1}\right)$ & $\left(\mathrm{cm} \mathrm{cm}^{-1}\right)$ \\
Buffalograss & $0.72 \mathrm{a}^{1}$ & $0.33 \mathrm{a}$ \\
Sideoats grama & $0.23 \mathrm{c}$ & $0.12 \mathrm{c}$ \\
Tobosagrass & $0.43 \mathrm{~b}$ & $0.22 \mathrm{~b}$ \\
\hline
\end{tabular}

${ }^{2}$ Means in the same column with the same letter are not significantly different $(\mathrm{P}>0.05)$

sideoats grama and tobosagrass grew more in basal diameter $(\mathrm{P}<0.01)$ than those with buffalograss. Juniper seedlings grew less in height with tobosagrass and buffalograss $(\mathrm{P}<0.01)$ than with sideoats grama or the no grass control. Woody

Table 2. Soil nutrient status in the open grassland or under the canopy of mesquite trees, under mesquite trees but with no root competition and in a sub-canopy position with the mesquite tree removed.

\begin{tabular}{|c|c|c|c|c|c|c|c|c|}
\hline & \multirow[b]{2}{*}{$\mathrm{pH}$} & \multicolumn{7}{|c|}{ Nutrient } \\
\hline & & $\mathrm{C}$ & $\mathrm{N}$ & $\mathrm{P}$ & $\mathrm{K}$ & $\mathrm{Mg}$ & $\mathrm{S}$ & $\mathrm{Na}$ \\
\hline & & $(\%)$ & $-\ldots-$. & $-\cdots$ & $\ldots \ldots$ & 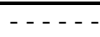 & $-\cdots$ & $\ldots \ldots$ \\
\hline \multicolumn{9}{|l|}{ Soil depth (mm) } \\
\hline $0-150$ & $7.9 b^{1}$ & $2.1 \mathrm{a}$ & $5.4 \mathrm{a}$ & $61 \mathrm{a}$ & $648 \mathrm{a}$ & $514 \mathrm{c}$ & $146 \mathrm{~b}$ & $19 \mathrm{c}$ \\
\hline $150-300$ & $8.4 \mathrm{a}$ & $1.1 \mathrm{~b}$ & $1.4 \mathrm{~b}$ & $37 \mathrm{~b}$ & $461 \mathrm{~b}$ & $742 \mathrm{~b}$ & $311 \mathrm{~b}$ & $26 \mathrm{c}$ \\
\hline $300-600$ & $8.4 \mathrm{a}$ & $0.8 \mathrm{c}$ & $1.1 \mathrm{~b}$ & $34 b$ & $268 \mathrm{c}$ & $1101 \mathrm{a}$ & $757 \mathrm{~b}$ & $276 \mathrm{~b}$ \\
\hline $600-900$ & $8.1 \mathrm{~b}$ & $0.5 \mathrm{c}$ & $1.0 \mathrm{~b}$ & $47 \mathrm{ab}$ & $286 \mathrm{c}$ & $1160 \mathrm{a}$ & $1879 \mathrm{a}$ & $644 \mathrm{a}$ \\
\hline \multicolumn{9}{|l|}{ Treatment } \\
\hline Mesquite Canopy & $8.2 \mathrm{a}$ & $1.3 \mathrm{a}$ & $3.2 \mathrm{a}$ & $39 a$ & $387 \mathrm{a}$ & $851 \mathrm{a}$ & $390 \mathrm{~b}$ & $163 \mathrm{~b}$ \\
\hline Mesquite removed & $8.3 \mathrm{a}$ & $1.2 \mathrm{ab}$ & $2.6 \mathrm{ab}$ & $56 \mathrm{a}$ & $408 \mathrm{a}$ & $907 \mathrm{a}$ & $683 \mathrm{~b}$ & $305 \mathrm{a}$ \\
\hline No Mesquite root & $8.1 \mathrm{a}$ & $1.1 \mathrm{ab}$ & $2.0 \mathrm{ab}$ & $46 \mathrm{a}$ & $455 \mathrm{a}$ & $864 \mathrm{a}$ & $210 b$ & $203 \mathrm{~b}$ \\
\hline Open Grassland & $8.4 \mathrm{a}$ & $0.9 \mathrm{~b}$ & $1.0 \mathrm{~b}$ & $37 \mathrm{a}$ & $414 \mathrm{a}$ & $895 \mathrm{a}$ & $1810 \mathrm{a}$ & $293 \mathrm{a}$ \\
\hline
\end{tabular}




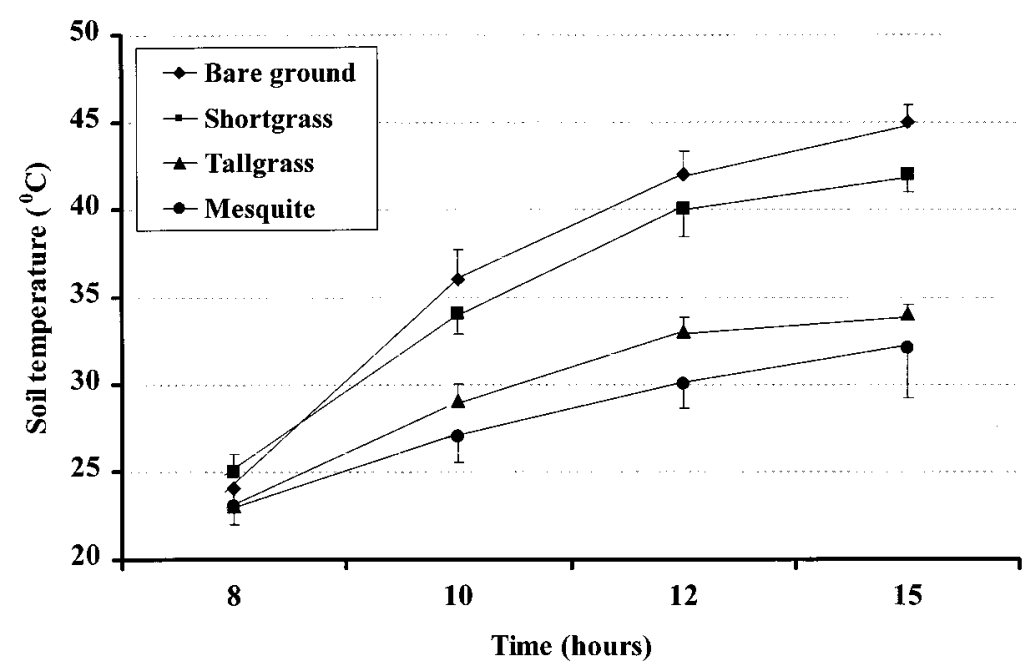

Fig. 1. Mean soil temperature at 1-cm depth for 6 days in June 1996 under bare ground, shortgrass, tallgrass and the canopy of mesquite trees. Bars indicate one-half of standard deviations for each time and location.

plant basal diameter is more closely related to plant biomass than plant height (Kramer and Kozlowski 1979) but when plant basal diameter differences are greater or smaller than plant height differences some differential effects on growth may be inferred. Greater height for a given biomass may indicate greater competition for light (Harper 1977).

In this study, juniper seedlings growing with buffalograss (short and palatable) grew less than those growing with sideoats grama (taller and palatable) or tobosagrass (taller and unpalatable). This was unexpected since taller grasses are generally more competitive than shorter grasses (Dyksterhuis 1958, Briske 1996) and palatable grasses are generally more competitive than unpalatable grasses (Moretto and Distel 1997). This indicates that the different growth rates of juniper seedlings in the presence of the different grasses in this study may be due to factors other than the differential competition of these species.

Soils under the taller, tufted grasses such as sideoats grama and tobosagrass have higher infiltration rates than shortgrasses like buffalograss (Thurow 1991). Although the amount of bare ground in sideoats grama patches was similar to buffalograss patches, but less than tobosagrass patches, the buffalograss patches were shorter and thus offered less shading of the soil surface. Litter cover was also less in the buffalograss patches $(\mathrm{P}<0.01)$ offering less shading of the soil surface than in sideoats grama and tobosagrass patches. This resulted in midgrass species, sideoats grama and tobosagrass, reducing soil temperature more (Fig 1) than the short buffalograss. Reduced growth of juniper seedlings in the buffalograss patches is probably related to the more stressful conditions in these shortgrass patches. Higher infiltration rates and shade levels may have resulted temperatures in the patches dominated by sideoats grama and tobosagrass, resulting in a less stressful micro-environment and higher growth rates of juniper seedlings observed in this study. The possibility that buffalograss patches were associated with patches of more droughty soils also needs to be investigated.

\section{Mesquite competition study}

Juniper seedlings in open grassland grew less $(\mathrm{P}<0.05)$ in basal diameter and height than those under any of the differently treated mesquite canopies (Table 4). Soil nutrient status appears to be more limiting to juniper seedling growth in the open grassland than in the mesquite canopy positions. The basal diameter of seedlings growing with mesquite canopy removed, increased less $(\mathrm{P}<0.05)$ than those growing under intact mesquite

Table 4. Relative growth rate (RGR) of juniper seedlings growing in open grassland or under the canopy of mesquite trees, under mesquite trees but with no root competition and in a subcanopy position with the mesquite tree removed.

\begin{tabular}{lcc}
\hline \hline Treatment & RGR & RGR \\
& Basal diameter & $\begin{array}{c}\text { Plant height } \\
\text { Pm mm }\end{array}$ \\
\hline Open grassland & $\left(\mathrm{mm} \mathrm{m}^{-1}\right)$ & $\left(\mathrm{cm} \mathrm{cm}^{-1}\right)$ \\
Canopy with root competition & $0.65 \mathrm{c}^{1}$ & $0.22 \mathrm{c}$ \\
Canopy with no root competition & $0.99 \mathrm{a}$ & $0.33 \mathrm{ab}$ \\
Canopy removal & $0.93 \mathrm{ab}$ & $0.37 \mathrm{a}$ \\
\hline
\end{tabular}
probably favors juniper growth. Most seedling mortality in other juniper species occurs during the hot dry months and is higher in open grassland than at the edge of established woody plants (Johnsen 1962, Burkhardt and Tisdale 1976, Jackson and Van Auken 1997). In this study taller grass also ameliorated temperatures in summer resulting in greater growth rates of juniper. It is also possible that hydraulic lift (Dawson 1993) may have influenced results. Seedlings under intact mesquite canopies grew more than seedlings with either isolated soil or with the tree canopy removed. These last 2 situations would not have hydraulic lift whereas the former may have.

The common occurrence of juniper seedlings growing under established mesquite canopies (McPherson et al. 1988) might also indicate that these plants are tolerant of lower light levels found in sub-canopy positions (Jackson and Van Auken 1997). It is possible that full sunlight may be a less favorable environment for young juniper plants than the partial shade of a mesquite canopy. In this study juniper growing under a mesquite canopy, in greater amounts of soil water and cooler

canopies with full root competition or with no root competition. A healthy grass sward is more limiting to growth of juniper seedlings than the canopy of mesquite trees. Mesquite trees clearly provide a relatively favorable environment for juniper seedlings. This must be due in part to the greater nutrient availability under mesquite canopies than in the surrounding grassland. Juniper growth in the presence of sub-canopy grasses with the mesquite tree removed was intermediate between those growing beneath intact mesquite trees and those growing in open grassland. However, it is counter-intuitive that seedlings growing with the mesquite trees removed grew less than those growing under an intact mesquite canopy with full root competition. The soil nutrient status was not different at these 2 locations. Low levels of shading under mesquite canopies ameliorate the temperature during periods of high temperature stress (Fig. 1) that

${ }^{1}$ Means in the same column with the same letter are not significantly different $(\mathrm{P}>0.05)$ 
but without mesquite root competition, grew no better than those with mesquite root competition, indicating that mesquite root competition with juniper is probably inconsequential. Since juniper grows mainly in fall, winter and spring when mesquite trees are dormant and leafless, lack of competition between these 2 woody species may largely be due to using resources at different times of the year. The higher nutrient availability beneath mesquite canopies, reduction of summer temperatures, and temporal separation of resource use clearly benefit juniper plants growing in the presence of mesquite trees compared to those growing in open grassland.

Clearly, managing for a vigorous grass component with low densities and cover of mesquite is the best way to limit the rate of invasion by juniper. Although juniper grew less with buffalograss than either sideoats grama or tobosagrass, this response may largely be due to microsite differences rather than the relative competitiveness among them. There is a need to determine how much the growth of juniper seedlings is impeded by competition with different grass species relative to possible microsite differences associated with the different species.

\section{Literature Cited}

Barth, R.C. and J.O. Klemmedson. 1978. Shrub-induced spatial patterns of dry matter, nitrogen and organic carbon. Soil Sci. Soc. Amer. J. 42:804-808.

Barth, R.C. and J.O. Klemmedson. 1982. Amount and distribution of dry matter, nitrogen and organic carbon in soil-plant systems of mesquite and Palo-verde. J. Range Manage. 35:412-418.

Briske, D.D. 1996. Strategies of plant survival in grazed systems: A functional interpretation, p. 37-67. In: J. Hodgson and A.W Illius (eds.), The ecology and management of grazing systems. CAB International, London.

Burkhardt, J.W. and E.W. Tisdale. 1976. Causes of juniper invasion in southwestern Idaho. Ecol. 57:472-484.

Dawson, T.E. 1993. Hydraulic lift and water use by plants - Implications for water balance, performance and plant-plant interactions. Oecologia 95:565-574.

Dreimanis, A. 1962. Quantitative gasometric determination of calcite and dolomite by using the Chittick apparatus. J. Sedimentary Petrology 32:520-529.

Dye, K.L., D.N. Ueckert, and S.G. Whisenant. 1995. Redberry juniper-herbaceous understory interactions. J. Range Manage. 48:100-107.

Dyksterhuis, E.J. 1958. Ecological principles in range evaluation. Bot. Rev. 24:253-272.
Evans, G.C. 1972. The quantitative analysis of plant growth. Blackwell, London

Fuhlendorf, S. D., F. E. Smeins, and W. E. Grant. 1996. Simulation of a fire-sensitive ecological threshold: A case study of Ashe juniper on the Edwards Plateau of Texas, USA. Ecol. Model. 90: 245-255.

Harper, J.L. 1977. Population biology of plants. Academic Press, London.

Hons, F.M., L.A. Larson-Vollmer, and M.A. Locke. 1990. $\mathrm{NH}_{4} \mathrm{O}$ ac-EDTA extractable phosphorus as a soil test procedure. Soil Sci. 149:249-256.

Jackson J.T. and O.W. van Auken. 1997. Seedling survival, growth and mortality of Juniperus ashei (Cupressacae) in the Edwards plateau region of central Texas. Texas J. Sci. 49:267-278.

Johnsen, T.N. 1962. One-seeded juniper invasion of northern Arizona grasslands. Ecol. Monogr. 32:187-207.

Johnson, P., A. Gerbolini, D. Ethridge, C. Britton, and D. Ueckert. 1999. Economics of redberry juniper control in the Texas Rolling Plains. J. Range Manage. 52:569-574.

Keeney, D.R. and D.W. Nelson. 1982. Nitrogen-inorganic forms, p. 643-698. In: A.L. Page, R.H. Miller, and D.R. Keeney (eds.), Methods of soil analysis. Part 2. Amer. Soc. Agron. Madison, Wis.

Kramer, P.J. and Kozlowski, T.T. 1979. Physiology of woody plants. Academic Press, New York.

McPherson, G.R. and H.A. Wright. 1987. Factors affecting reproductive maturity of redberry juniper (Juniperus pinchotii). Forest. Ecol. Manage. 21:191-196.

McPherson, G.R., H.A. Wright, and D.B. Wester. 1988. Patterns of shrub invasion in semi-arid Texas grasslands. Amer. Midland Naturalist 120:391-397.

Moretto, A.S. and R.A. Distel. 1997. Competitive interactions between palatable and unpalatable grasses native to a temperate semi-arid grassland of Argentina. Plant Ecol. 130:155-161.

Nelson, D.W. and L.E. Sommers. 1982. Total carbon, organic carbon and organic matter, $\mathrm{p}$. 539-579. In: A.L. Page, (ed.), Methods of soil analysis, Part 2. Agronomy Monograph 9. 2nd Ed. Soil Sci. Soc. Amer. Madison, Wis.

SAS Institute. 1988. SAS/STAT user's guide. SAS Institute, Cary, N.C.

Scifres, C.J. 1980. Brush management principles and practices for Texas and the southwest. Texas A\&M Univ. Press, College Station, Tex.

Schofield, R.K. and A.W. Taylor. 1955. The measurement of soil pH. Soil Sci. Soc. Amer. Proc. 19:164-167

Smith, M.A., H.A. Wright, and J.L. Schuster. 1975. Reproductive characteristics of redberry juniper. J. Range Manage. 28:126-128.
Thurow, T.L. 1991. Hydrology and erosion, p. 141-160. In: R.K. Heitschmidt and J.W. Stuth (eds). Grazing management: An ecological perspective. Timber Press, Portland, Ore.

Van Auken, O.W. 1993. Size distribution patterns and potential population change of some dominant woody species of the Edwards plateau region of Texas. Texas J. Sci. 45:199-210.

Virginia, R.A., W.M. Jarrell, W.G. Whitford, and D.W. Freckman. 1992. Soil biota and soil properties in the surface-rooting zone of mesquite (Prosopis glandulosa) in historical and recently desertified Chihuahuan desert habitats. Biol. Fertil. Soils 14:90-98 